\title{
Determinan Return Saham Industri Otomotif dan Komponen yang Terdaftar di BEI
}

\author{
Jaja Suteja \\ Fakultas Ekonomi Universitas Pasundan \\ Jl. Tamansari No. 6-8, Bandung 40116 \\ E-Mail: jajasuteja@unpas.ac.id \\ Patrisius Seran \\ Mahasiswa Magister Manajemen Fakultas Pascasarjana Universitas Pasundan \\ J1. Sumatera No. 41, Bandung 40117 \\ E-Mail: elpatrico7@gmail.com
}

\begin{abstract}
This study is aimed at determining the effect of Return on Equity (ROE), Debt to Equity Ratio (DER), Net Profit Margin (NPM), inflation, exchange rates, and interest rates on stock return of Automotive Industry and its Components. The method used is in this research is data panel regression and the period of research is from 2009 to 2013. The result showed that the ROE, DER, NPM, inflation, exchange rates, and interest rates affect the stock return of Automotive Industry and its Components. Partially, ROE and inflation positively affect the stock return, while the exchange rates and interest rates negatively affect the stock return. The rest, DER and NPM have no effect on stock return.
\end{abstract}

Keywords: inflation, BI rate, exchange rate, return on equity, debt to equity ratio, net profit margin, stock return.

\begin{abstract}
ABSTRAK
Penelitian ini bertujuan untuk mengetahui pengaruh dari Return on Equity (ROE), Debt to Equity Ratio (DER), Net Profit Margin (NPM), inflasi, nilai tukar, dan suku bunga terhadap return saham Industri Otomotif dan Komponen. Metode yang digunakan adalah metode regresi panel data dengan lama penelitian antara tahun 2009 sampai dengan 2013. Hasil penelitian menunjukkan bahwa ROE, DER, NPM, inflasi, nilai tukar, dan suku bunga memberikan pengaruh terhadap return saham Industri Otomotif dan Komponen. Secara parsial, ROE dan inflasi berpengaruh positif terhadap return saham, sedangkan nilai tukar dan suku bunga berpengaruh negatif terhadap return saham. Sisanya, DER dan NPM tidak memberikan pengaruh terhadap return saham.
\end{abstract}

Kata Kunci: inflasi, BI rate, nilai tukar, return on equity, debt to equity ratio, net profit margin, return saham. 


\section{PENDAHULUAN}

Industri otomotif dan komponen yang terdaftar di BEI dipandang memiliki peran penting dalam pertumbuhan laju perekonomian di Indonesia. Perusahaan otomotif dan komponen merupakan merupakan kelompok perusahaan go public yang menarik untuk dijadikan objek dalam penelitian ini karena mengalami perkembangan return saham industri otomotif dan komponen juga menunjukkan kinerja yang cukup baik. Selama tahun 2009 sampai dengan 2013, rata-rata return saham industri otomotif dan komponen yang terdaftar di Bursa Efek Indonesia (BEI) periode 2009-2013 mengalami fluktuasi. Return saham tertinggi terjadi pada tahun 2010 dengan ratarata return saham mencapai 2.25 atau $225 \%$. Return saham terendah terjadi pada tahun 2013 dengan return saham hingga -0.15 atau $-15 \%$.

Investasi yang dilakukan para investor diasumsikan selalu didasarkan pada pertimbangan rasional, sehingga berbagai jenis informasi diperlukan untuk pengambilan keputusan investasi. Keputusan investor tentunya sangat dipengaruhi oleh nilai return yang sebesar-besarnya dengan tingkat risiko tertentu. Return menjadi indikator utama bagi kemampuan perusahaan dalam menciptakan nilai bagi para investornya, biasanya dapat berupa capital gain maupun pembayaran dividen untuk investasi saham.
Dalam penentuan return saham ini dipengaruhi oleh kinerja perusahaan. Dengan demikian, pengukuran kinerja perusahaan ini menjadi salah satu faktor penting yang dapat digunakan bagi perencanaan keuangan perusahaan. Pengukuran kinerja melalui rasio-rasio keuangan dapat digunakan untuk menjelaskan kekuatan dan kelemahan keuangan perusahaan serta mempunyai kekuatan untuk memprediksi harga atau return saham di pasar modal.

Rasio keuangan pertama yang dapat digunakan untuk menganalisis kinerja perusahaan adalah ROE. ROE merupakan kemampuan perusahaan dengan modal sendiri untuk menghasilkan laba. Laba tersebut adalah laba yang tersedia bagi pemegang saham. Rasio ini memiliki relasi positif dengan return saham yang mana apabila ROE meningkat, maka return saham pun meningkat. Demikian sebaliknya, apabila ROE menurun maka return saham pun menurun.

DER merupakan rasio perbandingan utang terhadap modal. Rasio utang lebih besar daripada rasio modal pertanda bahwa sebagian besar modal perusahaan berasal dari utang. Besarnya utang menunjukkan besarnya risiko perusahaan tersebut oleh karena risiko jatuh tempo. Besarnya modal mengindikasikan tingkat keamanan perusahaan bersangkutan. Logika atas konsep ini adalah semakin besar utang, semakin kecil return saham sebaliknya semakin besar modal, semakin besar return saham.

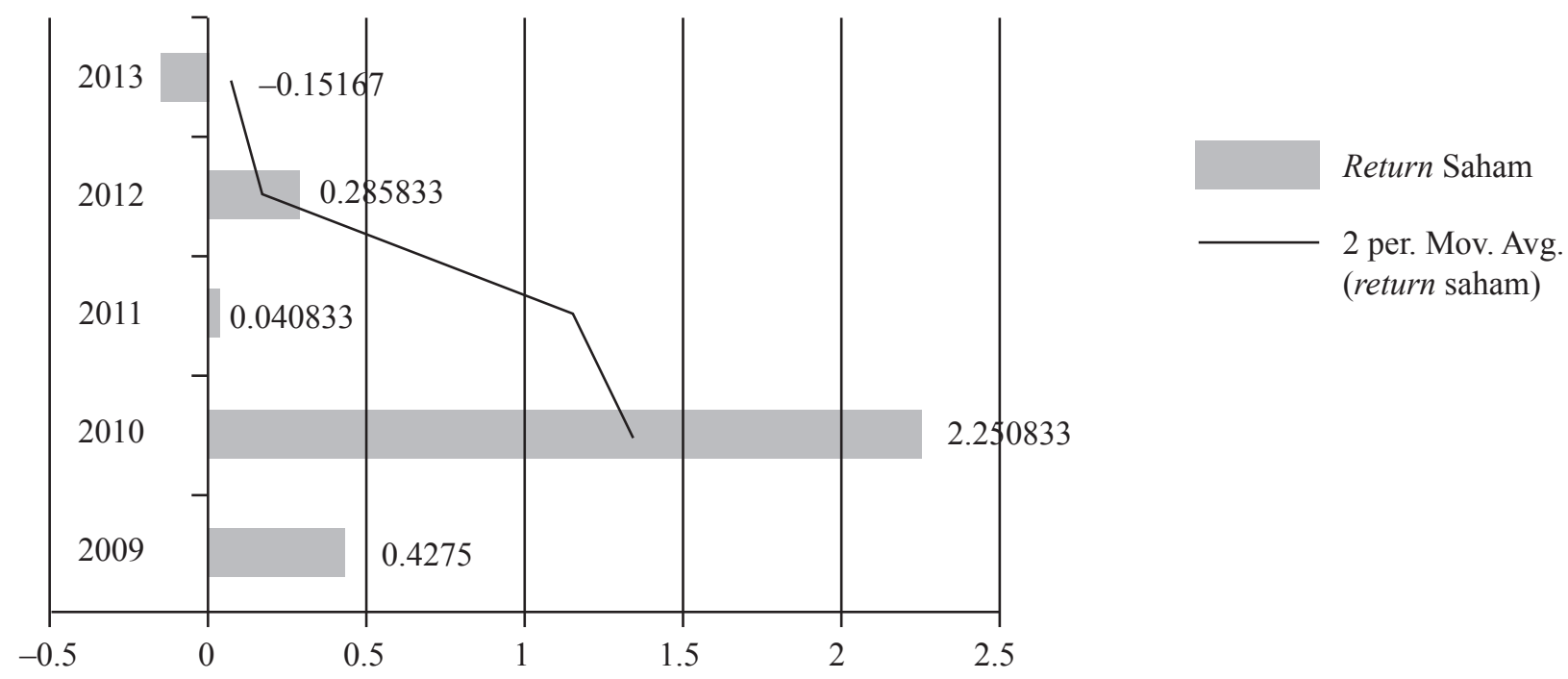

Gambar 1. Rata-rata Return Saham Industri Otomotif dan Komponen Periode 2009-2013 
Tabel 1. Rata-rata ROE, DER, NPM, Inflasi, Nilai Tukar, dan BI Rate

Industri Otomotif dan Komponen yang Terdaftar di BEI 2009-2013

\begin{tabular}{llllll}
\hline \multicolumn{1}{c}{ Variabel } & \multicolumn{1}{c}{$\mathbf{2 0 0 9}$} & \multicolumn{1}{c}{$\mathbf{2 0 1 0}$} & $\mathbf{2 0 1 1}$ & \multicolumn{1}{c}{$\mathbf{2 0 1 2}$} & \multicolumn{1}{c}{$\mathbf{2 0 1 3}$} \\
\hline ROE & 0,668333 & 0,196667 & 0,148333 & 0,141667 & 0,096667 \\
DER & 1,944167 & 1,453333 & 1,203333 & 1,015 & 1,0125 \\
NPM & 0,0675 & 0,095833 & 0,081667 & 0,090833 & 0,059167 \\
Inflasi & 2,8 & 7 & 3,8 & 4,28 & 7,15 \\
Nilai Tukar & 9.400 & 8.991 & 9.068 & 9.670 & 10.562 \\
BI Rate & 6,5 & 6,5 & 6,58 & 5,77 & 6,5 \\
\hline
\end{tabular}

Sumber: Bank Indonesia dan ICMD, 2014 (data diolah)

NPM menunjukkan laba bersih yang diperoleh perusahaan. Semakin besar NPM mengindikasikan bahwa kinerja perusahaan semakin produktif. Hal ini dapat meningkatkan kepercayaan investor untuk menanamkan modalnya pada perusahaan tersebut. Rasio ini juga menunjukkan besarnya persentase laba bersih yang diperoleh dari setiap penjualan. Semakin besar rasio ini, semakin baik kemampuan perusahaan untuk mendapatkan laba yang tinggi. Hal ini mengundang investor untuk berinvestasi dalam saham perusahaan bersangkutan.

Selain dipengaruhi oleh faktor kinerja perusahaan, dalam menentukan return saham juga dipengaruhi faktor eksternal. Faktor tersebut meliputi faktor makroekonomi. Kemampuan investor dalam memahami dan meramalkan kondisi makroekonomi di masa datang akan sangat berguna dalam pembuatan keputusan investasi yang menguntungkan. Untuk itu, investor harus mempertimbangkan beberapa indikator makroekonomi yang dapat membantu investor dalam membuat keputusan investasinya.

Indikator makroekonomi yang sering dikaitkan dengan pasar modal adalah fluktuasi tingkat inflasi, kurs rupiah, dan suku bunga. Inflasi merupakan salah satu makroekonomi yang menunjukkan kenaikan harga berbagai produk dan jasa dalam suatu periode tertentu. Kondisi ini mempengaruhi kemampuan daya beli konsumen dalam membeli produk atau jasa sehingga kinerja perusahaan dalam bentuk laba serta return kepada investor yang dihasilkan.

Kurs rupiah mencerminkan posisi nilai tukar suatu negara (home currency) terhadap negara lain (foreign currency). Mengingat nilai tukar rupiah mengacu kepada dollar AS, ketika terjadi pelemahan nilai rupiah terhadap dollar AS, maka perusahaan- perusahaan yang menjual produknya dalam bentuk mata uang dollar akan mengalami keuntungan karena nilainya menjadi besar ketika dikonversi ke dalam mata uang rupiah. Hal ini akan berpengaruh juga terhadap return yang didapatkan oleh shareholders.

BI rate digunakan sebagai acuan dalam pelaksanaan operasi pengendalian moneter untuk mengarahkan agar rata-rata tertimbang suku bunga SBI satu bulan hasil lelang operasi pasar terbuka berada di sekitar BI rate. Selanjutnya, suku bunga SBI dengan tenor satu bulan diharapkan mempengaruhi suku bunga pasar uang antar bank dan suku bunga jangka yang lebih panjang. Tingkat suku bunga yang tinggi akan meningkatkan biaya modal yang akan ditanggung perusahaan dan juga akan menyebabkan required rate of return investor dari suatu investasi akan meningkat.

Tabel 1 memperlihatkan secara jelas faktor kinerja perusahaan (ROE, DER, dan NPM) dan makroekonomi (inflasi, nilai tukar, dan suku bunga BI) yang terjadi dalam industri otomotif dan komponen yang terdaftar di BEI. Kecenderungan yang terlihat adalah bahwa baik faktor faktor fundamental maupun makroekonomi relatif stabil selama lima tahun terakhir (2009-2013). Kestabilan faktor makroekonomi dan faktor fundamental perusahaan, tidak diikuti dengan kestabilan dalam return saham, sehingga return saham perusahaan terus merugi.

Penelitian empiris mengenai ROE, DER, dan NPM sudah banyak dilakukan, namun demikian penggunaan variabel-variabel tersebut masih jarang dilakukan secara bersamaan. Dilihat dari sisi objek penelitian, ternyata belum banyak dilakukan penelitian menggunakan ketiga rasio tersebut. Penelitian menggunakan ketiga rasio tersebut menjadi 
suatu terobosan dan tantangan tersendiri untuk membuktikannya. Hal ini ditambah pula dengan keberadaan faktor-faktor makroekonomi (inflasi, nilai tukar, dan suku bunga) yang memperkuat dan memperluas variabel penelitian ini. Mengingat masih adanya pertentangan dalam kajian sebelumnya, maka dirasa perlu untuk melakukan penelitian mengenai determinan return saham di Industri Otomotif dan Komponen.

Berdasarkan latar belakang di atas, maka rumusan masalah dalam penelitian ini adalah apakah ROE, DER, NPM, inflasi, nilai tukar, dan suku bunga terhadap return saham. Tujuan penelitian ini adalah untuk memperoleh bukti empiris pengaruh ROE, DER, NPM, inflasi, nilai tukar, dan suku bunga terhadap return saham.

\section{Pengaruh ROE terhadap Return Saham}

Dalam hal pengaruh hubungan ROE terhadap return saham, Martani et al. (2009), dalam penelitiannya menemukan bahwa ROE berhubungan positif dan signifikan terhadap return saham. Gunardi (2010) menemukan bahwa perubahan ROE berpengaruh positif terhadap perubahan harga saham. Hasil analisis dari penelitian Yogo (1998) menunjukkan bahwa ROE dapat digunakan dalam menentukan proyeksi dan variasi harga saham. Deitiana (2013) dalam hasil penelitiannya menunjukkan bahwa ROE berpengaruh terhadap harga saham. Penelitian Sudiyatno dan Suharmanto (2011) menemukan pengaruh negatif dan signifikan terhadap return saham. Hasil penelitian Susilowati dan Turyanto (2011) menunjukkan bahwa ROE tidak berpengaruh terhadap return saham. Hasil yang berbeda dinyatakan oleh Artha et al. (2014) menjelaskan bahwa ROE tidak memberikan pengaruh terhadap harga saham. Taufik (2007) menjelaskan hasil penelitiannya menemukan bahwa ROE tidak mempunyai pengaruh yang signifikan terhadap tingkat pengembalian saham pada perusahaan perbankan di BEJ. Wijaya (2008) menunjukkan ROE tidak memiliki pengaruh secara signifikan dan positif terhadap return. Hasil yang sama juga ditunjukkan dari hasil penelitian Harjito dan Aryayoga (2009), yang juga menemukan bahwa ROE tidak berpengaruh signifikan terhadap return saham di BEI.

\section{Pengaruh DER terhadap Return Saham}

Terkait dengan analisis DER dan kaitannya dengan return saham, Artha et al. (2014) mengemukakan bahwa DER berpengaruh terhadap harga saham.
Hasil penelitian Susilowati dan Turyanto (2011) menunjukkan bahwa DER terbukti berpengaruh positif terhadap return saham. Sutriani (2014) hasil penelitiannya menunjukkan DER berpengaruh positif terhadap return. Penelitian yang dilakukan Natarsyah (2000) menunjukkan DER berpengaruh positif dan signifikan terhadap return saham. Hermawan (2012) menyatakan bahwa DER berpengaruh negatif terhadap return saham secara signifikan. Penelitian yang dilakukan Liestyowati (2002) menunjukkan bahwa DER berpengaruh negatif sebelum dan selam krisis terhadap return saham. Hasil analisis dari penelitian Yogo (1998) menunjukkan bahwa DER cenderung tidak dapat digunakan dalam menentukan proyeksi dan variasi harga saham. Hasil pengujian statistik dari penelitian Suharli (2005) menunjukkan bahwa DER tidak mempengaruhi return saham secara signifikan.

\section{Pengaruh NPM terhadap Return Saham}

Bukti empiris penelitian yang mendukung seperti dilakukan oleh Asyik dan Soelistyo (2000) menunjukkan bahwa NPM berpengaruh signifikan terhadap laba perusahaan. Hasil penelitian Susilowati dan Turyanto (2011) menunjukkan bahwa NPM tidak berpengaruh terhadap return saham. Haryanto dan Sugiharto (2003) menunjukkan bahwa NPM tidak berpengaruh signifikan terhadap harga saham. Hermawan (2012) menyatakan bahwa NPM tidak berpengaruh terhadap return saham. Harjito dan Aryayoga (2009), yang juga menemukan bahwa NPM tidak berpengaruh signifikan terhadap return saham di BEI.

\section{Pengaruh Inflasi terhadap Return Saham}

Penelitian terkait pengaruh inflasi terhadap return saham juga menunjukkan hasil yang beragam. Penelitian yang dilakukan Purnamawati dan Werastuti (2013), inflasi mempunyai pengaruh yang positif dalam jangka panjang pada harga saham. Sohail dan Hussain (2012)menyatakan bahwa inflasi berpengaruh signifikan terhadap return saham di pasar modal India dan Pakistan. Butt et al. (2009) menjelaskan bahwa inflasi lebih berpengaruh terhadap return saham untuk level industri dibandingkan level perusahaan. Ratanapakorn dan Sharma (2007) juga menemukan pengaruh positifterhadap return saham. Hooker(2004) menemukan bahwa tingkat inflasi mempengaruhi secara signifikan terhadap harga saham. Rusliati dan Fathoni (2011) menyebutkan bahwa inflasi secara parsial berpengaruh negatif terhadap return saham. 
Hasil yang sama juga ditemukan oleh Rjoub et al. (2009) dan Flannery \& Protopapadakis (2002). Terdapat juga hasil yang berbeda dikemukakan oleh Sodikin (2007), inflasi memiliki pengaruh yang lemah terhadap return saham. Janor et al. (2010) menjelaskan hasil penelitian di Malaysia bahwa inflasi tidak memiliki hubungan signifikan dengan return saham. Kewal (2012) menunjukkan bahwa inflasi tidak memberikan pengaruh terhadap IHSG. Kurniadi et al. (2014) juga mengemukakan bahwa inflasi tidak berpengaruh signifikan terhadap return saham sektor pertanian. Halim (2013) juga menemukan bahwa inflasi tidak berpengaruh terhadap return. Utami dan Rahayu (2003) menyatakan inflasi tidak berpengaruh terhadap return.

\section{Pengaruh Nilai Tukar terhadap Return Saham}

Penelitian empiris mengenai nilai tukar terhadap return saham terdapat hasil yang juga relatif beragam. Hasil penelitian Sohail dan Hussain (2012) menunjukkan bahwa nilai tukar berpengaruh signifikan terhadap return saham. Halim (2013) menemukan bahwa nilai tukar berpengaruh terhadap return saham kapitalisasi besar. Artha et al. (2014) menjelaskan bahwa pergerakan kurs rupiah memberikan pengaruh negatif terhadap harga saham. Soenen dan Hennigan (1988) juga menjelaskan bahwa nilai tukar berpengaruh negatif terhadap harga saham. Purnamawati dan Werastuti (2013), kurs mempunyai pengaruh yang positif dalam jangka panjang pada harga saham. Utami dan Rahayu (2003) menemukan nilai tukar mempunyai pengaruh secara signifikan terhadap harga saham selama periode krisis ekonomi. Kewal (2012) mengemukakan bahwa kurs berpengaruh negatif signifikan terhadap IHSG. Wongbangpo dan Sharma (2002) menemukan bahwa nilai tukar memiliki hubungan positif dengan harga saham di Negara Indonesia, Malaysia, dan Filipina, sebaliknya berhubungan negatif di Singapura dan Thailand. Kandir (2008) menunjukkan nilai kurs mempengaruhi secara positif terhadap return dari semua portofolio yang ada. Hasil yang berbeda dikemukakan Sodikin (2007) mengemukakan nilai tukar mempunyai pengaruh yang lemah terhadap return saham. Kurniadi et al. (2014) menjelaskan bahwa nilai tukar tidak berpengaruh signifikan terhadap return saham sektor pertanian. Mok (1993) menunjukkan hasil bahwa tidak ada hubungan yang signifikan antara nilai tukar dengan harga saham pada pasar saham terbuka dan tertutup di Hong Kong.
Penelitian Prasetiono (2010) menyimpulkan bahwa dalam jangka pendek kurs yang tidak signifikan.

\section{Pengaruh Suku Bunga terhadap Return Saham}

Artha et al. (2014) menjelaskan bahwa BI rate memberikan pengaruh negatif terhadap harga saham. Utami dan Rahayu (2003) menemukan suku bunga berpengaruh terhadap harga saham. Hooker (2004) juga menemukan bahwa tingkat bunga berpengaruh negatif terhadap return pasar. Gjerde dan Sættem (1999) memperoleh hasil perubahan suku bunga riil berpengaruh secara negatif dengan harga saham. Hasil penelitian Kandir (2008) di mana tingkat bunga mempengaruhi secara negatif return semua portofolio yang diteliti. Wongbangpo dan Sharma (2002) menemukan bahwa terdapat hubungan negatif antara tingkat bunga dan harga saham di Filipina, Singapura, dan Thailand, sedangkan hubungan positif terjadi di Negara Indonesia dan Malaysia. Hasil penelitian tersebut juga didukung oleh Chiarella dan Gao (2004). Sementara hasil berbeda ditunjukkan oleh penelitian yang dilakukan Kewal (2012) menunjukkan bahwa suku bunga tidak memberikan pengaruh terhadap IHSG. Mok (1993) menunjukkan hasil bahwa tidak ada hubungan yang signifikan antara tingkat bunga dengan harga saham pada pasar saham terbuka dan tertutup di Hong Kong. Halim (2013) menjelaskan bahwa tidak terdapat pengaruh BI rate terhadap return. Penelitian Prasetiono (2010) menyimpulkan bahwa dalam jangka pendek suku bunga SBI tidak signifikan.

\section{Hipotesis}

Berdasarkan kajian terdahulu, maka dalam penelitian ini dapat dirumuskan hipotesis sebagai berikut: 1) ROE, DER, NPM, Inflasi, nilai tukar, dan suku bunga berpengaruh terhadap return saham. 2) ROE berpengaruh terhadap return saham. 3) DER berpengaruh terhadap return saham. 4) NPM berpengaruh terhadap return saham. 5) Inflasi berpengaruh terhadap return saham. 6) Nilai tukar berpengaruh terhadap return saham. 7) Suku bunga berpengaruh terhadap return saham.

\section{METODE}

\section{Rancangan Penelitian}

Jenis penelitian ini merupakan basic research dengan pendekatan kuantitatif, yaitu penelitian dengan menggunakan hipotesis dengan menggunakan 
alat uji statistik untuk menyimpulkan hipotesis yang menggunakan causal hypothesis. Explanatory hypothesis atau causal hypothesis adalah hipotesis yang menyatakan hubungan satu variabel yang menyebabkan perubahan variabel lain (Sekaran, 2007).

\section{Populasi dan Sampel}

Populasi yang digunakan dalam penelitian ini adalah Industri Otomotif dan Komponen sebanyak 13 perusahaan. Data dikumpulkan dengan menggunakan teknik purposive sampling, yaitu teknik penentuan sampel dengan pertimbangan tertentu (Sugiyono, 2013). Beberapa kriteria dalam pemilihan sampel adalah perusahaan yang tercatat di Bursa Efek Indonesia (BEI) selama tahun 2009-2013, tersedia data laporan keuangan selama kurun waktu penelitian (tahun 2009-2013), dan tidak di-delisting dalam kurun waktu 2009-2013, maka jumlah sampel industri otomotif dan komponen yang memenuhi kriteria adalah sebanyak 12 perusahaan.

Tabel 3. Sampel Penelitian

\begin{tabular}{ll}
\hline No. & \multicolumn{1}{c}{ Nama Perusahaan } \\
\hline 1. & Astra International Tbk \\
2. & Astra Otoparts Tbk. \\
3. & Gajah Tunggal Tbk. \\
4. & Goodyear Indonesia Tbk. \\
5. & Indo Kordsa Tbk. \\
6. & Indomobil Sukses Internasional Tbk. \\
7. & Indospring Tbk. \\
8. & Multi Prima Sejahtera Tbk. \\
9. & Multistrada Arah Sarana Tbk. \\
10. & Nipress Tbk. \\
11. & Prima Alloi Steel Tbk. \\
12. & Selamat Sempurna Tbk. \\
\hline
\end{tabular}

\section{Model Analisis}

Model yang digunakan dalam penelitian ini adalah analisis regresi data panel. Model persamaan yang digunakan adalah sebagai berikut:

$$
\begin{aligned}
\mathrm{R}_{\mathrm{it}}= & \alpha+\beta_{1} \mathrm{ROE}_{\mathrm{it}}+\beta_{2} \mathrm{DER}_{\mathrm{it}}+\beta_{3} \mathrm{NPM}_{\mathrm{it}}+\beta_{4} \mathrm{INF}_{\mathrm{it}}+ \\
& \beta_{5} \mathrm{NT}_{\mathrm{it}}+\beta_{6} \mathrm{SB}_{\mathrm{it}}+\varepsilon_{\mathrm{it}}
\end{aligned}
$$

Di mana:

$$
\begin{array}{ll}
i & : \text { n saham perusahaan } \\
t & : \text { n tahun pengamatan } \\
\alpha & : \text { intercept }
\end{array}
$$

$\beta_{i} \quad$ : koefisien regresi variabel bebas (slope)

$R_{i t} \quad$ : return saham $i$ pada tahun $t$

$R O E_{i t}:$ nilai ROE $i$ tahun $t$

$D E R_{i t}:$ nilai DER $i$ tahun $t$

$N P M_{i t}$ : nilai NPM $i$ tahun $t$

$I N F_{i t}$ : nilai inflasi $i$ pada tahun $t$

$N T_{i t}$ : nilai mata uang rupiah terhadap US dollar $i$ tahun $t$

$S B_{i t} \quad$ : nilai suku bunga $i$ tahun $t$

$\varepsilon \quad:$ Error

\section{Pemilihan Model Terbaik}

Untuk memilih model terbaik dari tiga pendekatan, yaitu model pooled least square (PLS), model fixed effect, dan model random effect diperlukan sebuah alat pengujian model tersebut. Ada tiga alat pengujian untuk memilih model panel data, yaitu uji Chow (Chow test) dan uji Hausman (Hausman test). Uji Chow digunakan untuk memilih apakah model PLS atau Fixed Effect. Uji Hausman digunakan untuk memilih Model Fixed Effect atau Random Effect.

\section{HASIL}

\section{Uji Chow}

Data yang digunakan dalam penelitian ini merupakan data yang stasioner dan menyebar normal. Data merupakan data unbalance karena ada beberapa data perusahaan yang tidak tersedia di sumber data.

Nilai $p(0,9398)>$ alpha $5 \%$ maka terima $\mathrm{H}_{0}$, artinya model yang terbaik adalah Pooled Least Square (PLS). Berdasarkan Tabel 4 yang menyajikan hasil perhitungan uji Chow, maka $\mathrm{H}_{0}$ diterima dan $\mathrm{H}_{1}$ ditolak, yaitu dalam penelitian ini pendekatan Pooled Least Square lebih baik daripada pendekatan dengan model Fixed Effect.

Tabel 3. Hasil Uji Chow

\begin{tabular}{cccc}
\hline Effects Test & Statistic & d.f. & Prob. \\
\hline Cross-section F & 0,417946 & $(11,42)$ & 0,9398 \\
\hline
\end{tabular}

\section{Analisis Model Regresi Panel Data}

Berdasarkan hasil uji chow yang memilih model Pooled Least Square sebagai model terbaik, berikut hasil dari model PLS.

Hasil analisis regresi pada Tabel 4. menunjukkan bahwa faktor ROE, DER, NPM, inflasi, kurs, dan suku bunga, secara bersama-sama memberikan pengaruh terhadap return saham. Banyaknya cross section (i) adalah dua belas perusahaan dan data time series adalah lima tahun. 
Tabel 4. Hasil Model Regresi Panel Data

\begin{tabular}{|c|c|c|c|c|}
\hline Variable & Coefficient & Std. Error & t-Statistic & Prob. \\
\hline $\mathrm{C}$ & 58.56441 & 9.166196 & 6.389172 & 0.0000 \\
\hline $\mathrm{ROE}$ & 1.890237 & 0.949011 & 1.991797 & 0.0516 \\
\hline DER & 0.237552 & 0.187567 & 1.266489 & 0.2109 \\
\hline NPM & 0.814236 & 0.615961 & 1.321896 & 0.1919 \\
\hline INF & 0.177501 & 0.074913 & 2.369420 & 0.0215 \\
\hline NT & -6.155333 & 1.007723 & -6.108161 & 0.0000 \\
\hline $\mathrm{SB}$ & -0.511985 & 0.271543 & -1.885464 & 0.0649 \\
\hline \multicolumn{5}{|c|}{ Weighted Statistics } \\
\hline R-squared & 0.297475 & \multicolumn{2}{|c|}{ Mean dependent var } & 0.581340 \\
\hline $\begin{array}{l}\text { Adjusted } \\
\text { R-squared }\end{array}$ & 0.217944 & \multicolumn{2}{|c|}{ S.D. dependent var } & 1.298548 \\
\hline $\begin{array}{l}\text { S.E. of } \\
\text { regression }\end{array}$ & 1.182402 & \multicolumn{2}{|c|}{ Sum squared resid } & 74.09801 \\
\hline F-statistic & 3.740354 & \multicolumn{2}{|c|}{ Durbin-Watson stat } & 2.410091 \\
\hline $\begin{array}{l}\text { Prob } \\
\text { (F-statistic) } \\
\end{array}$ & 0.003554 & & & \\
\hline \multicolumn{5}{|c|}{ Unweighted Statistics } \\
\hline R-squared & 0.282117 & \multicolumn{2}{|c|}{ Mean dependent var } & 0.570500 \\
\hline $\begin{array}{l}\text { Sum } \\
\text { squared } \\
\text { resid }\end{array}$ & 105.9839 & \multicolumn{2}{|c|}{ Durbin-Watson stat } & 2.783142 \\
\hline
\end{tabular}

$\mathrm{R}_{\mathrm{it}}=58,56+1,89 \mathrm{ROE}_{\mathrm{it}}+0,24 \mathrm{DER}_{\mathrm{it}}+0,81 \mathrm{NPM}_{\mathrm{it}}$ $+0,18 \mathrm{INF}_{\mathrm{it}}-6,15 \mathrm{NT}_{\mathrm{it}}-0,51 \mathrm{SB}_{\mathrm{it}}+\varepsilon_{\mathrm{it}}$

Koefisien ROE terhadap return saham adalah positif, hal ini menunjukkan bahwa kenaikan ROE sebesar 1\% (ceteris paribus), maka akan menyebakan peningkatan return saham sebesar 1,89\%. DER terhadap return saham adalah positif, hal ini menunjukkan bahwa kenaikan DER sebesar 1\% (ceteris paribus), maka akan menyebakan peningkatan return saham sebesar $0,24 \%$. NPM terhadap return saham adalah positif, hal ini menunjukkan bahwa kenaikan NPM sebesar 1\% (ceteris paribus), maka akan menyebakan peningkatan return saham sebesar $0,81 \%$.

Koefisien inflasi terhadap return saham adalah positif, hal ini menunjukkan bahwa kenaikan inflasi sebesar 1\% (ceteris paribus), maka akan menyebakan peningkatan return saham sebesar $0,18 \%$. Koefisien nilai tukar terhadap return saham adalah negatif, hal ini menunjukkan bahwa kenaikan nilai tukar sebesar 1\% (ceteris paribus), maka akan menyebakan penurunan return saham sebesar $6,15 \%$. Koefisien sku bunga terhadap return saham adalah negatif, hal ini menunjukkan bahwa kenaikan suku bunga sebesar 1\% (ceteris paribus), maka akan menyebakan penurunan return saham sebesar $0,51 \%$.

Nilai $\mathrm{R}^{2}$ menunjukkan bahwa variabel $\mathrm{ROE}$, DER, NPM, inflasi, kurs, dan suku bunga mampu menjelaskan pengaruhnya terhadap return saham sebesar 29,75\%, sedangkan sisanya 70,25\% dijelaskan oleh faktor lain (dan tidak dimasukan ke dalam persamaan). Variabel ROE, inflasi, kurs, dan suku bunga berpengaruh signifikan pada level $10 \%$, sedangkan variabel DER dan NPM tidak memiliki pengaruh signifikan terhadap return saham.

\section{PEMBAHASAN}

\section{Pengaruh ROE, DER, NPM, Inflasi, Nilai Tukar, dan Suku Bunga terhadap Return Saham}

Hasil penelitian ini membuktikan bahwa secara simultan, ROE, DER, NPM, inflasi, nilai tukar, dan suku bunga berpengaruh terhadap return saham. Nilai kontribusi pengaruh dari model penelitian adalah sebesar $29,75 \%$. Hal ini menunjukkan bahwa kemampuan variabel-variabel independen dalam menjelaskan fluktuasi yang terjadi pada variabel dependen sebesar $29,75 \%$, sedangkan sisanya $70,25 \%$ dijelaskan oleh variabel-variabel lain di luar model penelitian ini.

Investor sebaiknya memperhatikan faktor-faktor fundamental keuangan yang mencerminkan kinerja keuangan perusahaan faktor makroekonomi selain return saham itu sendiri sebelum memutuskan untuk berinvestasi. Faktor-faktor fundamental tersebut diantaranya adalah ROE, DER, dan NPM, serta faktor makroekonomi seperti inflasi, nilai tukar dan suku bunga.

Saham-saham emiten yang memiliki kinerja keuangan yang baik dapat dijadikan pilihan untuk berinvestasi karena berpengaruh terhadap return saham. Faktor fundamental yang tercermin dalam laporan keuangan sangat diperlukan oleh para investor, sehingga dapat digunakan sebagai sinyal positif untuk menilai return saham. Dengan demikian, hal ini dapat digunakan oleh manajemen sebagai sinyal untuk meningkatkan kemakmuran para pemegang saham.

\section{Pengaruh ROE terhadap Return Saham}

Variabel ROE memiliki probabilitas 0.0516 serta koefisien 1,89 dengan alpha 10\%. Hal ini berarti bahwa ROE berpengaruh positif signifikan terhadap return saham. Hasil penelitian ini sesuai dengan 
penelitian Martani et al. (2009), Gunardi (2010), Yogo (1998), dan Deitiana (2013) yang menemukan bahwa ROE berpengaruh positif signifikan terhadap return saham. Hasil ini sesuai dengan teori bahwa ROE merupakan tolak ukur profitabilitas, di mana para pemegang saham pada umumnya ingin mengetahui tingkat probabilitas modal saham dan keuntungan yang telah mereka investasikan kembali dalam bentuk laba yang ditanam. Apabila saham perusahaan diperdagangkan di bursa saham, tinggi rendahnya ROE akan mempengaruhi tingkat permintaan saham tersebut di bursa dan harga jualnya. Hal ini berarti bahwa ROE sebagai informasi direspon positif oleh para pelaku bursa. Kondisi ini disebabkan karena pola distribusi data dari return saham yang cenderung naik ketika ROE meningkat.

\section{Pengaruh DER terhadap Return Saham}

Variabel DER memiliki probabilitas 0.2109 serta koefisien 0,24 dengan alpha 10\%. Hasil ini menunjukkan berarti bahwa DER tidak berpengaruh signifikan terhadap return saham. Hasil penelitian ini sejalan dengan penelitian Yogo (1998) dan Suharli (2005) yang menjelaskan hasil penelitiannya bahwa DER tidak berpengaruh terhadap return saham. Hasil ini mengindikasikan adanya pertimbangan yang berbeda dari beberapa investor dalam memandang DER. Oleh sebagian investor, DER dipandang besarnya tanggung jawab perusahaan terhadap pihak ketiga, yaitu kreditur yang memberikan pinjaman kepada perusahaan, sehingga semakin besar nilai DER akan memperbesar tanggungan perusahaan. Namun demikian nampaknya beberapa investor justru memandang bahwa perusahaan yang tumbuh pasti akan memerlukan utang sebagai dana tambahan untuk memenuhi pendanaan pada perusahaan yang tumbuh. Perusahan tersebut memerlukan banyak dana operasional yang tidak mungkin dapat dipenuhi hanya dari modal sendiri yang dimiliki perusahaan. Kondisi ini menyebabkan kemungkinan berkembangnya perusahaan di masa yang akan datang yang berujung pada meningkatnya return saham. Namun demikian, tidak berpengaruhnya DER terhadap return saham berarti tinggi rendahnya DER perusahan tidak mempengaruhi tinggi rendahnya return saham perusahaan Industri Otomotif dan Komponen yang Listing di BEI

\section{Pengaruh NPM terhadap Return Saham}

Variabel NPM memiliki probabilitas 0.1919 serta koefisien 0,81 dengan alpha 10\%. Hasil ini menjelaskan bahwa NPM tidak memiliki pengaruh signifikan terhaadap return saham. Susilowati \& Turyanto (2011), Haryanto \& Sugiharto (2003), Hermawan (2012), dan Harjito \& Aryayoga (2009), menjelaskan hasil penelitiannya bahwa NPM tidak berpengaruh terhadap return saham. Hasil penelitian yang tidak signifikan antara NPM dan return saham disebabkan adanya fluktuasi pada data NPM yang digunakan dalam penelitian selain itu juga karena perusahaan tidak mampu menghasilkan keuntungan (laba), sehingga mempengaruhi investor maupun calon investor untuk melakukan investasi. Keadaan yang terjadi saat itu adalah investor tidak bersedia membeli saham dengan harga tinggi dengan nilai NPM perusahaan rendah, akibatnya NPM tidak mempengaruhi tingkat pengembalian (return) perusahaan tersebut. Dengan demikian, tidak berpengaruhnya DER terhadap return saham berarti tinggi rendahnya NPM perusahan tidak mempengaruhi tinggi rendahnya return saham perusahaan Industri Otomotif dan Komponen yang Listing di BEI

\section{Pengaruh Inflasi terhadap Return Saham}

Variabel inflasi memiliki probabilitas $0.0215 \mathrm{serta}$ koefisien 0,18 dengan alpha $10 \%$. Halini berartibahwa inflasi berpengaruh positif terhadap return saham. Hasil penelitian ini selaras dengan hasil penelitian Purnamawati \& Werastuti (2013), Sohail dan Hussain (2012), Butt et al. (2009), Ratanapakorn \& Sharma (2007), dan Hooker (2004) yang menyatakan bahwa tingkat inflasi berpengaruh positif secara signifikan terhadap return saham. Investor memahami bahwa dengan adanya inflasi tidak akan membahayakan dananya yang berada di Bursa. Intervensi pemerintah dalam menangani laju inflasi juga memberikan kepercayaan diri yang tinggi bagi investor untuk tetap berinvestasi di bursa. Indikasi lain disebabkan karena di Negara berkembang seperti Indonesia menunjukkan bahwa pada beberapa emerging stock market inflasi berkorelasi secara positif dengan return saham.

\section{Pengaruh Nilai Tukar terhadap Return Saham}

Variabel nilai tukar memiliki probabilitas 0.0000 serta koefisien -6,15 dengan alpha 10\%. Hasil ini menunjukkan berarti bahwa nilai tukar memiliki pengaruh signifikan negatif terhadap return saham. Hal ini berarti sesuai dengan penelitian Artha et al. (2014), Soenen \& Hennigan (1988), Kewal (2012), dan Wangbangpo \& Sharma (2002). Hal ini mengindikasikan bahwa hubungan antara kurs rupiah dan harga saham berlawanan arah, artinya semakin 
kuat kurs rupiah terhadap US\$ (rupiah terapresiasi), maka akan menurunkan return saham, dan sebaliknya. Kemungkinan lain dengan melemahnya nilai tukar dapat mengakibatkan keuntungan pada pasar modal, sehingga menyebabkan pasar saham akan memberikan daya tarik kepada investor.

\section{Pengaruh Suku Bunga terhadap Return Saham}

Variabel suku bunga memiliki probabilitas 0.0649 serta koefisien -0,51 dengan alpha 10\%. Hasil ini menjelaskan bahwa suku bunga memiliki pengaruh negatif terhadap return saham. Artha et al. (2014), Hooker (2004), Gjerde \& Sættem (1999), Kandir (2008), dan Wongbangpo \& Sharma (2002) memperkuat hasil penelitian ini bahwa suku bunga memiliki pengaruh negatif terhadap return saham. Kenaikan tingkat suku bunga BI rate ini akan menurunkan return saham. Hal ini menandakan bahwa tingkat kepekaan dari variabel perubahan return saham Industri Otomotif dan Komponen dalam merespon perubahan tingkat suku bunga BI lebih besar. Indikasi ini menyabkan investor akan menginvestasikan dananya pada investasi yang memberikan return lebih besar dengan risiko yang rendah. Dengan penurunan suku bunga, maka investor akan cenderung tertarik berinvestasi dalam bentuk saham yang memberikan return yang lebih besar, sehingga permintaan terhadap saham pun meningkat, sehingga berdampak pada peningkatan harga saham. Dengan kata lain, tingkat suku bunga yang tinggi, mengakibatkan kecenderungan investor untuk menabung menjadi tinggi dan selera berinvestasi pada saham menjadi berkurang.

\section{KESIMPULAN}

Berdasarkan hasil analisis seperti yang telah dijelaskan, maka dapat ditarik kesimpulan sebagai berikut: 1) Hasil penelitian ini membuktikan bahwa secara simultan, ROE, DER, NPM, inflasi, nilai tukar, dan suku bunga berpengaruh terhadap return saham. 2) ROE berpengaruh positif terhadap return saham.

3) DER tidak berpengaruh terhadap return saham.

4) NPM tidak berpengaruh terhadap return saham.

5) Inflasi berpengaruh positif terhadap return saham.

6) Nilai tukar berpengaruh negatif terhadap return saham. 7) Suku bunga berpengaruh negatif terhadap return saham. Dalam memperoleh return saham yang besar, pihak manajemen harus lebih berani dalam memanfaatkan segala ekuitas yang dimiliki dengan berbagai pertimbangan pendapatan dan risiko tertentu. Dengan demikian, investor pun akan semakin tertarik untuk melakukan investasi di pasar modal dan Sebagai investor maupun calon investor disarankan untuk selalu mengamati perkembangan kinerja internal keuangan perusahaan dan kondisi makroekonomi.

\section{DAFTAR PUSTAKA}

Artha, Danika Reka, Noer Azam Achsani, \& Hendro Sasongko. 2014. Analisis Fundamental, Teknikal, dan Makroekonomi Harga Saham SektorPertanian. Jurnal Manajemen dan Kewirausahaan, 16(2): 175-184.

Asyik, NurFajrih\&Soelistyo.2000.KemampuanRasio Keuangan dalam Memprediksi Laba (Penetapan Rasio Keuangan sebagai Discriminator). Jurnal Ekonomi dan Bisnis Indonesia, 15(3): 313-331.

Butt, B. Z., Rehman, K. U., Khan, M. A., \& Safwan, N. 2009. Do Economic Factors Influence Stock Return? A Firm and Industry Level Analysis. African Journal of Business Management, 4(5): 583-593.

Chiarella Carl \& Gao Shenhuai. 2004. The Value of The S\&P 500 -A Macro View of The Stock Market Adjustment Process. Global Finance Journal, 15: 171-196.

Deitiana, Tita. 2013. Pengaruh Current Ratio, Return on Equity, dan Total Asset Turn Over terhadap Dividend Payout Ratio dan Implikasi pada Harga Saham Perusahaan LQ 45. Jurnal Bisnis dan Akuntansi, 15(1): 82-88.

Flannery, Mark J. \& Protopapadakis, Aris A. 2002. Macroeconomic Factors Do Influence Agregate Stock Returns. The Review of Financial Studies, 15(3): 751-782.

Gjerde, Øystein \& Frode Sættem. 1999. Causal Relations Among Stock Returns and Macroeconomic Variables in A Small, Open Economy. Journal of International Financial Markets, Institutions and Money, 9: 61-74.

Gunardi, Ardi. 2010. Perubahan Kinerja Keuangan terhadap Perubahan Harga Saham pada Perusahaan Food and Beverages. Jurnal Riset Bisnis dan Manajemen, 3(1): 11-20.

Halim, Livia. 2013. Pengaruh Makro Ekonomi terhadap Return Saham Kapitalisasi Pasar di Bursa Efek Indonesia. FINESTA, 1(2): 108-113. 
Harjito, D. Agus \& Rangga Aryayoga. 2009. Analisis Pengaruh Kinerja Keuangan dan Return Saham di Bursa Efek Jakarta. Fenomena. 7(1): 13-21.

Haryanto \& Toto Sugiharto. 2003. Pengaruh Rasio Profitabilitas terhadap Harga Saham pada Perusahaan Industri di Bursa Efek Jakarta. Jurnal Ekonomi dan Bisnis, 8(3): 141-154.

Hermawan, Dedi Aji. 2012. Pengaruh Debt to Equity Ratio, Earning per Share, dan Net Profit Margin terhadap Return Saham. Management Analysis Journal, 1(5): 1-7.

Hooker, Mark A. 2004. Macroeconomic Factors and Emerging Market Equity Returns: A Bayesian Model Selection Approach. Emerging Markets Review, 5: 379-387.

Janor, Hawati, Ruzita Abdul Rahim, Mohd Hasimi Yaacob \& Izani Ibrahim. 2010. Stock Returns and Inflation with Supply and Demand Shocks: Evidence from Malaysia. Jurnal Ekonomi Malaysia, 44(2010): 3-10.

Kandir, Serkan Yilmaz. 2008. Macroeconomic Variables, Firm Characteristics and Stock Returns: Evidence from Turkey. International Research Journal of Finance and Economics, 16: 35-45.

Kewal, Suramaya Suci. 2012. Pengaruh Inflasi, Suku Bunga, Kurs, dan Pertumbuhan PDB terhadap Indeks Harga Saham Gabungan. Jurnal Economia, 8(1): 53-64.

Kurniadi, Arif, Noer Azam Achsani \& Hendro Sasongko. 2014. Kinerja Keuangan Berbasis Penciptaan Nilai, Faktor Makroekonomi, dan ReturnSaham Sektor Pertanian.JurnalManajemen dan Kewirausahaan, 16(2): 141-152.

Liestyowati. 2002. Faktor yang Mempengaruhi Keuntungan Saham di Bursa Efek Jakarta: Analisis Periode Sebelum dan Selama Krisis. Jurnal Manajemen Indonesia, 1(2): 40-50.

Martani, Dwi, Mulyono \& Rahfiani Khairurizka. 2009. The Effect of Financial Ratios. Firm Size. and Cash Flow From Operating Activitiesin the Interim Report to the Stock Return. Chinese Business Review. 8(6): 44-55.

Mok, Henry MK. 1993. Causality of Interest Rate, Exchange rate, and Stock price at Stock Market Open and close in Hong Kong. Asia Pacific Journal of Management, 10: 123-129.

Natarsyah, Syahib. 2000. Analisis Pengaruh Beberapa Faktor Fundamental Perusahaan terhadap Harga Saham (Kasus Industri Barang Konsumsi). Jurnal Ekonomi dan Bisnis Indonesia, 5(3): 294-312.
Prasetiono, Dwi Wahyu. 2010. Analisis Pengaruh Faktor Fundamental Ekonomi Makro dan Harga Minyak terhadap Saham LQ45 dalam Jangka Pendek dan Jangka Panjang. Journal of Indonesian Applied Economics, 4(1): 11-25.

Purnamawati, I Gusti Ayu \& Desak Nyoman Sri Werastuti. 2013. Faktor Fundamental Ekonomi Makro terhadap Harga Saham LQ45. Jurnal Keuangan dan Perbankan, 17(2): 211-219.

Ratanapakorn, O. \& Sharma, S. C. 2007. Dynamic analysis between the US stock returns and the macroeconomic variables. Applied Financial Economics, 17(5): 369-377.

Rjoub, Husam, Turgut Tursoy \& Nil Gunsel Resatoglu. 2009. The Effects of Macroeconomic Factors on Stock Returns: Instanbul Stock Market. Studies in Economic and Finance Journal, 26(1): 36-45.

Rusliati, Ellen. 2011. Inflasi, Suku Bunga Deposito, dan Return Pasar terhadap Return Saham pada Industri Barang Konsumsi yang Terdaftar di BEI 2006-2009. Jurnal Bisnis dan Akuntansi, 13(2): 107-118

Sekaran, Uma. 2007. Research Methods for Business. Jakarta: Salemba Empat.

Sodikin, A. 2007. Variabel Makro Ekonomi yang Mempengaruhi Return Saham di BEJ. Jurnal Manajemen, 6(2): 1-15.

Soenen L. A. \& Hennigar E. S. 1988. An Analysis of Exchange Rates and Stock Prices: The US experience between 1980 and 1986. Akron Business and Economic Review, 19: 71-76.

Sohail, Nadeem \& Zakir Hussain. 2012. Macroeconomic Policies and Stock Returns in Pakistan: A Comparative Analysis of Three Stock Exchanges. Interdisciplinary Journal of Contemporary Research and Business, 3(10): 905-918.

Sudiyatno, Bambang \& Toto Suharmanto. 2011. Kinerja Keuangan Konvensional, Economic Value Added, dan Return Saham. Jurnal Dinamika Manajemen, 2(2): 153-161.

Suharli, Michell. 2005. Studi Empiris terhadap Dua Faktor yang Mempengaruhi Return Saham Pada Industri Food \& Beverages di Bursa Efek Jakarta. Jurnal Akuntansi dan Keuangan, 7(2): 99-116.

Susilowati, Yeye dan Tri Turyanto. 2011. Reaksi Signal Rasio Profiabilitas dan Rasio Solvabilitas terhadap Return Saham Perusahaan. Dinamika Keuangan dan Perbankan, 3(1): 17-37. 
Sutriani, Anis. 2014. Pengaruh Profitabilitas, Leverage, dan Likuiditas Terhadap Return Saham dengan Nilai Tukar Sebagai Variabel Moderasi Pada Saham LQ-45. Journal of Business and Banking, 4(1): 67-80.

Taufik. 2007. Pengaruh Pendekatan Traditional Accounting dan Economic Value Added Terhadap Stock Return Perusahaan Sektor Perbankan di PT. Bursa Efek Jakarta. Jurnal Manajemen \& Bisnis Sriwijaya, 5(10): 1-14.

Utami, Mudji \& Mudjilah Rahayu. 2003. Peranan Profitabilitas, Suku Bunga, Inflasi dan Nilai Tukar dalam Mempengaruhi Pasar Modal Indonesia Selama Krisis Ekonomi. Jurnal Manajemen \& Kewirausahaan, 5(2): 123-131.
Wijaya, David. 2008. Pengaruh Rasio Modal Saham Terhadap Return Saham Perusahaan-Perusahaan Telekomunikasi Go Public di Indonesia Periode 2007. Jurnal Manajemen dan Kewirausahaan, 10(2): 136-152.

Wongbangpo, Praphan dan Subhash C. Sharma. 2002. Stock Market and Macroeconomic Fundamental Dynamic Interaction: ASEAN-5 Countries. Journal of Asian Economics, 13: 27-51.

Yogo, Purnomo. 1998. Keterkaitan Kinerja Keuangan dengan Harga Saham. Usahawan, 12: 33-38. 